\title{
Perubahan Perilaku Budaya Appasilli Pada Suku Makassar Untuk Mengurangi Permasalahan Stunting
}

\author{
Laurent Nadia Asmoro Putri \\ Institut Ilmu Kesehatan Strada Indonesia \\ laurentnadia154@gmail.com
}

\begin{abstract}
Abstrak
Pemahaman dari perspektif bahasa, kata budaya atau kebudayaan berasal dari Bahasa Sansekerta yaitu buddhayah, yang merupakan bentuk jamak dari buddhi (budi atau akal) diartikan sebagai hal-hal yang berkaitan dengan budi dan akal manusia. Dalam Bahasa Inggris, kebudayaan disebut culture, yang berasal dari kata Latin Colere, yaitu mengolah atau mengerjakan, bisa diartikan juga sebagai mengolah tanah atau bertani. Kata culture dalam Bahasa Inggris diterjemahkan dalam Bahasa Indonesia sebagai "kultur".Stunting atau sering disebut pendek adalah kondisi gagal tumbuh pada anak berusia di bawah lima tahun (balita) akibat kekurangan gizi kronis dan stimulasi psikosisial serta paparan infeksi berulang terutama dalam 1.000 Hari Pertama Kehidupan (HPK), yaitu dari janin hingga anak berusia dua tahun.Anak tergolong stunting apabila panjang atau tinggi badannya berada dibawah minus dua standar deviasi (-2SD) anak seusianya. Kemampuan Ibu untuk melaksanakan apa yang dipercaya dan apa yang dilakukan dalam hal pengasuhan anak dilihat dari praktik pemberian makan pada anak dan keluarga, pemberian ASI Esklusif, dan makanan pendamping ASI (MP-ASI).Sosial budaya yang dimaksud adalah kepercayaan, nilai dan norma yang dianut, dan segala pantangan makan selama masa kehamilan dan setelah persalinan pada Ibu yang memiliki anak stunting di suku Makassar Kecamatan Turatea, Kabupaten Jeneponto.
\end{abstract}

\section{Kata Kunci : Stunting,Pola Asuh dan Pola Makan Keluarga ,Sosial Budaya}

\section{Latar Belakang}

Pemahaman dari perspektif bahasa, kata budaya atau kebudayaan berasal dari Bahasa Sansekerta yaitu buddhayah, yang merupakan bentuk jamak dari buddhi (budi atau akal) diartikan sebagai hal-hal yang berkaitan dengan budi dan akal manusia. Dalam Bahasa Inggris, kebudayaan disebut culture, yang berasal dari kata Latin Colere, yaitu mengolah atau mengerjakan, bisa diartikan juga sebagai mengolah tanah atau bertani. Kata culture dalam Bahasa Inggris diterjemahkan dalam Bahasa Indonesia sebagai "kultur". 
Stunting atau sering disebut pendek adalah kondisi gagal tumbuh pada anak berusia di bawah lima tahun (balita) akibat kekurangan gizi kronis dan stimulasi psikosisial serta paparan infeksi berulang terutama dalam 1.000 Hari Pertama Kehidupan (HPK), yaitu dari janin hingga anak berusia dua tahun. Anak tergolong stunting apabila panjang atau tinggi badannya berada dibawah minus dua standar deviasi (-2SD) anak seusianya.

Menurut data yang dilansir dari World Health Organization (WHO), pada 1990 silam jumlah anak yang stunting di dunia mencapai 225 juta anak, dan pada tahun 2015 angka ini berhasil ditekan menjadi 156 juta anak atau sebesar 23,2\% mengalami stunted. Namun, bukan berarti masalah sudah selesai. Apabila tren berlanjut tanpa upaya penurunan, diproyeksikan akan menjadi 227 juta pada tahun 2025. Bahkan angka ini masuk dalam lima besar Negara dengan prevalensi stunting tertinggi di Asia Afrika dibandingkan beberapa Negara tetangga di ASEAN.

Menurut WHO, prevalensi balita pendek menjadi masalah kesehatan masyarakat jika prevalensinya $20 \%$ atau lebih. Karenanya persentase balita pendek di Indonesia masih tinggi. Prevalensi balita stunting di 24 Kabupaten/Kota se-Provinsi Sulawesi Selatan pada tahun 2015 menunjukkan bahwa Kabupaten dengan prevalensi balita stunting terbesar yaitu Kabupaten Jeneponto dengan persentase $47,3 \%$.

Sosial budaya perawatan kehamilan yang masih dipercaya dan dilakukan secara turun temurun oleh masyarakat suku Makassar di Kecamatan Turatea Kabupaten Jeneponto adalah upacara 7 bulanan atau disebut juga dengan upacara adat Appasilli. Ibu hamil di Kecamatan Turatea Kabupaten Jeneponto juga menghindari atau pantang makan buah berwarna kuning, sepeti nanas, pisang, dan papaya. Mereka percaya bahwa mengkonsumsi buah tersebut dapat mengakibatkan sesuatu atau malapetaka untuknya dan si calon bayi, sedangkan untuk penolong persalinan, Ibu masih memeriksakan kehamilannya di layanan kesehatan, namun sebagian dari informan jika merasakan sakit perut masih percaya dengan adanya dukun.

Dalam pola asuh dan pola makan keluarga, peran pengasuhan Ibu sangatlah minim, ada perbedaan antara jenis makanan yang dikonsumsi keluarga dengan makanan yang sering dikonsumsi oleh anak dengan status gizi stunting. Tidak adanya ASI Esklusif, dan makanan pendamping ASI yang diberikan terlalu dini juga menjadi faktor pemicu terjadinya stunting pada suku Makassar di Kecamatan Turatea Kabupaten Jeneponto.

\section{Kasus/Masalah}

Dari uraian latar belakang diatas dapat dirumuskan masalah sebagai berikut: Bagaimana cara mengubah perilaku budaya Appasilli pada suku Makassar. 


\section{Tinjauan Pustaka}

\subsection{Definisi Budaya}

Pemahaman dari perspektif bahasa, kata budaya atau kebudayaan berasal dari Bahasa Sansekerta yaitu buddhayah, yang merupakan bentuk jamak dari buddhi (budi atau akal) diartikan sebagai hal-hal yang berkaitan dengan budi dan akal manusia. Dalam Bahasa Inggris, kebudayaan disebut culture, yang berasal dari kata Latin Colere, yaitu mengolah atau mengerjakan, bisa diartikan juga sebagai mengolah tanah atau bertani. Kata culture dalam Bahasa Inggris diterjemahkan dalam Bahasa Indonesia sebagai "kultur".(Wikipedia)

\subsection{Definisi Stunting}

Stunting atau sering disebut pendek adalah kondisi gagal tumbuh pada anak berusia di bawah lima tahun (balita) akibat kekurangan gizi kronis dan stimulasi psikosisial serta paparan infeksi berulang terutama dalam 1.000 Hari Pertama Kehidupan (HPK), yaitu dari janin hingga anak berusia dua tahun.1 Anak tergolong stunting apabila panjang atau tinggi badannya berada di bawah minus dua standar deviasi (-2SD) anak seusianya.( Kementerian Kesehatan RI)

\subsection{Definisi Sosial Budaya dan Kejadian Stunting}

Banyak faktor yang memengaruhi status gizi anak, baik faktor langsung maupun faktor tidak langsung. Budaya merupakan salah satu faktor tidak langsung yang memengaruhi status gizi anak. Budaya merupakan salah satu faktor yang memengaruhi sikap Ibu di dalam menjalani masa kehamilannya, menjalani proses persalinan, serta dalam pengasuhan balita. Budaya, tradisi, atau kebiasaan yang ada dalam masyarakat seperti pantangan makan, dan pola makan yang salah dapat mengakibatkan munculnya masalah gizi terutama bagi balita. Hal ini dapat berdampak terhadap pertumbuhan dan perkembangan balita (Adriani et al, 2013).

World Health Organization (WHO, 2016) memperlihatkan bahwa penurunan berat badan biasanya mulai terjadi pada usia 6 bulan dimana akhir dari periode pemberian ASI Eksklusif. Penemuan tersebut diperkuat dengan ditemukannya dua per tiga balita yang meninggal mempunyai pola makan yang salah, yang penyebabnya antara lain tidak mendapatkan ASI eksklusif, mendapatkan nutrisi yang terlalu dini dan atau terlambat disertai komposisi zat gizi yang tidak lengkap, tidak seimbang dan tidak higienis (WHO, 2017). 


\section{Pembahasan}

\subsection{Perilaku Budaya Appasilli Pada Suku Makassar}

Kebudayaan adalah hasil cipta, rasa dan karsa manusia baik yang bersifat materi, maupun yang nonmateri. Suku Makassar adalah nama Melayu untuk sebuah etnis yang mendiami pesisir selatan pulau Sulawesi. Lidah Makassar menyebutnya Mangkassara' berarti mereka yang bersifat terbuka. Etnis Makassar ini adalah etnis yang berjiwa penakluk namun demokratis dalam memerintah, gemar berperang dan jaya di laut. Suku makassar yang biasa menyebut diri mereka sebagai orang Mangasara' atau to Mangkasara'. Sebagian besar berdiam di Kabupaten Gowa, Takalar, Jeneponto, Bantaeng, Maros dan Pangkajene di Provinsi Sulawesi Selatan.

Sosial budaya perawatan kehamilan yang masih dipercaya dan dilakukan secara turun temurun oleh masyarakat suku Makassar di Kecamatan Turatea Kabupaten Jeneponto adalah upacara 7 bulanan atau disebut juga dengan upacara adat Appasilli. Ibu hamil di Kecamatan Turatea Kabupaten Jeneponto juga menghindari atau pantang makan buah berwarna kuning, sepeti nanas, pisang, dan papaya. Mereka percaya bahwa mengkonsumsi buah tersebut dapat mengakibatkan sesuatu atau malapetaka untuknya dan si calon bayi, sedangkan untuk penolong persalinan, Ibu masih memeriksakan kehamilannya di layanan kesehatan, namun sebagian dari informan jika merasakan sakit perut masih percaya dengan adanya dukun.

Masyarakat Suku Makassar menganggap bahwa budaya (adat) itu keramat dan sakral. Oleh karenanya setiap peninggalan leluhur yang masih kental dianut oleh masyarakat Makassar, akan selalu berlaku dan dianut dalam berkehidupan sehari-hari, termasuk proses kehamilan hingga persalinan dan tumbuh kembang masyarakatnya.

Dampak dari perilaku budaya appasilli pada suku Makassar sangatlah berpengaruh pada gizi bayi sehingga hal ini sangat berdampak pada kejadian stunting. Yang dimana gizi merupakan kebutuhan dasar bagi seorang anak untuk berkembang secara optimal. Penelitian terkini menunjukkan dengan pemberian gizi yang benar pada 1000 hari pertama kehidupan dapat menentukan kualitas hidup anak baik dalam jangka pendek maupun dalam jangka panjang. SerIbu hari pertama kehidupan dimulai sejak masa selama kehamilan 270 hari (9 bulan) dalam kandungan dan 730 hari (2 tahun pertama) pasca lahir. Pemberian gizi yang tidak benar (malnutrisi) yang terjadi pada awal kehidupan akan berdampak berat pada kehidupan selanjutnya. 


\subsection{Faktor Penyebab Terjadinya Stuting}

\section{Sosial Budaya}

Sosial budaya yang dimaksud adalah kepercayaan, nilai dan norma yang dianut, dan segala pantangan makan selama masa kehamilan dan setelah persalinan pada Ibu yang memiliki anak stunting di suku Makassar Kecamatan Turatea, Kabupaten Jeneponto.

\section{Pola Asuh dan Pola Makan Keluarga}

Pola asuh dan pola makan keluarga adalah kemampuan Ibu untuk melaksanakan apa yang dipercaya dan apa yang dilakukan dalam hal pengasuhan anak dilihat dari praktik pemberian makan pada anak dan keluarga, pemberian ASI Esklusif, dan makanan pendamping ASI (MPASI)

\subsection{Opini Penulis}

Tingginya faktor budaya appasilli pada suku Makassar,Maka kita perlu melakukan promosi kesehatan bawasannya budaya appasilli sangat berpengaruh pada kebutuhan gizi Ibu tidak terpenuhi makan kekurangan energi protein (Kek) bisa saja terjadi, dan bila berlanjut maka bisa saja Ibu hamil mengalami Kekurangan energi kronik (KEK) yaitu keadaan Ibu menderita kekurangan makanan yang berlangsung menahun (kronis) yang mengakibatkan timbulnya gangguan kesehatan. KEK pada Ibu hamil berdampak terhadap Ibu dan bayi yang akan dilahirkan, seperti pertumbuhan janin yang kurang dan meningkatnya risiko kematian neonatal, meningkatnya risiko terjadinya stunting, dan berat badan lahir rendah atau BBLR.

\section{Kesimpulan}

Berdasarkan uraian diatas dapat disimpulkan bahwa upaya untuk menurunkan angka stunting padda suku Makassar adalah dengan melakukan promosi kesehatan bawasannya budaya appasilli sangat berpengaruh tidak baik dalam kebutuhan gizi ibu hamil maupun bayi yang akan dilahirkan. 


\section{Daftar Pustaka}

Albiner, Siagia. (2010). Epidemiologi Gizi. Jakarta: Erlangga Medical Series

Antonius Sumawartomo 2013. Kebudayaan dan Etnik Masyarakat. Jakarta

Pemantauan Status Gizi (PSG 2015). Direktural Jenderal Kesehatan Masyarakat. Jakarta.

http://repositori.uin-alauddin.ac.id/

https://indonesia.go.id/narasi/indonesia-dalam-angka/sosial/kementerian-kesehatan-fokus-padapencegahan-stunting

https://id.wikipedia.org/wiki/Budaya

Waode et al, (2017). Perbedaan pengetahuan, sikap, dan motivasi Ibu sesudah diberikan program mother smart grounding (msg) dalam pencegahan stunting di wilayah kerja puskesmas puuwatu kota kendari tahun 2017. 2017;2(6):1-9.

WHO. 2015. Infant and young child feeding. Who.inf/medicastrol 